\title{
Colony Incompatibility among New Zealand Isolates of Salmonella typhimurium
}

\author{
By K. A. BETTELHEIM \\ National Health Institute, Department of Health, Wellington, New Zealand
}

(Received 6 February 1978; revised 5 April 1978)

Strains of Salmonella typhimurium representing various phage-types were permitted to swarm towards each other on soft agar to determine their compatibility. Some strains, regardless of phage-type, were totally compatible, whereas others regularly formed incompatibility zones. The widths of these zones varied from less than $1 \mathrm{~mm}$ to $12 \mathrm{~mm}$. A detailed study of 30 strains of phage-types 1 and 42 showed that they belonged to a variety of incompatibility groups, while four strains of phage-type 179 , which was only recently found in New Zealand, all belonged to one incompatibility group.

\section{INTRODUCTION}

The Dienes phenomenon of Proteus (Coetzee, 1972; Senior, 1977) was considered to be peculiar to this group of bacteria until Bettelheim \& Carlile (1976) showed that, with suitably adjusted media, a similar phenomenon of colony incompatibility could be demonstrated among other enterobacteriaceae. In a preliminary study, Bettleheim (1977) described various incompatibility reactions, and showed that in Salmonella typhimurium the $\mathrm{H}$ antigen played no role in this phenomenon.

Of the $S$. typhimurium strains isolated in New Zealand, phage-types 1 and 42 are most common and a method of subdividing them was sought. Phage-type 179 had not been described in New Zealand before 1977 (S. M. Harding, personal communication) and it was considered possible that all four strains found represented a single clone.

This paper describes the compatibility testing of a random selection of strains isolated in New Zealand during 1977 and a detailed study of strains representing phage-types 1, 42 and 179.

\section{METHODS}

Bacterial strains and medium. The three type strains for phage-types 1, 42 and 179 were from the Hospital Crossinfection Section of the National Health Institute and are designated T01, T42 and T179, respectively. Wild strains of $S$. typhimurium were isolated in many parts of New Zealand and sent to the National Health Institute in Wellington for identification. The strain numbers and their sources are listed in Table 1.

The medium used for all these studies consisted of $\left(\mathrm{g}^{-1}\right.$ in distilled water): Bacto Tryptone (Difco), 10; $\mathrm{NaCl}, 5$; Bacto agar (Difco), 3.5. Petri dishes were surface-dried by leaving them at $4{ }^{\circ} \mathrm{C}$ for 2 to $3 \mathrm{~d}$.

Full motility was induced in all the strains by passage through semi-solid motility agar and the cultures were subsequently stored at room temperature on Dorset egg slopes. Regular subculture in broth followed by microscopic examination showed that during the course of these studies the strains maintained their full motility.

Test for compatibility. Two test strains were inoculated at either side of a Petri dish which was then incubated at $37^{\circ} \mathrm{C}$ for $4 \mathrm{~d}$. Dishes were examined daily in a darkened room under oblique lighting for incompatibility reactions, and the zones of growth were marked on the bottom of the dish. Tests of each strain against itself were included. The different reactions between strains were scored as degrees of incompatibility (Table 2). Being based on subjective observations, complete reproducibility of scoring in successive experiments 
Table 1. Strains of Salmonella typhimurium, their regions of isolation in New Zealand and their incompatibility groups

\begin{tabular}{|c|c|c|c|}
\hline Strain no. & Phage type & Region of isolation & $\begin{array}{c}\text { Incompatibility } \\
\text { group } \\
\text { (see Table 3) }\end{array}$ \\
\hline T01 & 1 & Type strain & III \\
\hline $\mathrm{X} 185$ & 1 & Nelson & III \\
\hline $\mathrm{X} 232$ & 1 & Christchurch & III \\
\hline $\mathrm{X} 317$ & 1 & Ruakura & VII \\
\hline X397 & 1 & Tauranga & III \\
\hline $\mathrm{X} 407$ & 1 & Christchurch & III \\
\hline $\mathrm{X} 428$ & 1 & Auckland & III \\
\hline $\mathrm{X} 483$ & 1 & Dunedin & III \\
\hline X484 & 1 & Dunedin & III \\
\hline X521* & 1 & Dunedin & III \\
\hline X522* & 1 & Dunedin & III \\
\hline X523 & 1 & Auckland & III \\
\hline X532 & 1 & Gisborne & III \\
\hline B44 & 1 & Hastings & IV \\
\hline B647 & 1 & Wellington & IV \\
\hline B173 & 26 & Wellington & II \\
\hline B179 & 26 & Auckland & II \\
\hline B798 & 26 & Otahuhu & I \\
\hline T42 & 42 & Type strain & III \\
\hline $\mathrm{X} 63$ & 42 & Christchurch & VIII \\
\hline $\mathrm{X} 134$ & 42 & Napier & III \\
\hline $\mathrm{X} 166$ & 42 & Wellington & III \\
\hline $\mathrm{X} 242$ & 42 & Auckland & $\mathrm{V}$ \\
\hline $\mathrm{X} 323$ & 42 & Ruakura & III \\
\hline X324 & 42 & Auckland & III \\
\hline $\mathrm{X} 332$ & 42 & New Plymouth & III \\
\hline X334* & 42 & Auckland & $\mathrm{V}$ \\
\hline X335* & 42 & Auckland & III \\
\hline X392 & 42 & Christchurch & IX \\
\hline X398* & 42 & Tauranga & $\mathrm{V}$ \\
\hline X399* & 42 & Tauranga & V \\
\hline $\mathrm{X} 405$ & 42 & Christchurch & $\mathrm{V}$ \\
\hline B356 & 42 & Wellington & III \\
\hline B43 & 101 & Whangarei & $\mathrm{XI}$ \\
\hline $\mathrm{X} 427 \dagger$ & 135 & Auckland & XI \\
\hline T179 & 179 & Type strain & $\mathrm{x}$ \\
\hline $\mathrm{X} 414 \dagger$ & 179 & Auckland & XI \\
\hline X600 & 179 & Auckland & XI \\
\hline B1123 & 179 & Auckland & XI \\
\hline B1162 & 179 & Auckland & XI \\
\hline B175 & NT $\ddagger$ & Auckland & VI \\
\hline
\end{tabular}

* The three pairs of strains, X521/X522, X334/X335 and X398/X399, were isolated from pairs of members of the same families.

$\dagger$ The pair of strains $\mathrm{X} 427 / \mathrm{X} 414$ was isolated from the same patient who had a mixed infection.

$\ddagger$ NT, Not typable.

with the same pairs of strains was not always achieved, but the differences were within one arbitrary unit. All tests were done more than once and the range of scores is given.

Test for bacteriocin production. Selected strains were tested against each other for the production of bacteriocins by the method of Abbott \& Shannon (1958).

\section{RESULTS}

The types of reactions which were observed between strains varied from a complete merging of two apposing strains, as was seen with two identical inocula, to the formation of a clear zone more than $10 \mathrm{~mm}$ wide between the two bacterial swarms (Fig. 1 $a, b$ ). 
Table 2. Scoring of cbserved interaction of swarms of Salmonella typhimurium

Score

Observation

0 Total or partial merging of swarms, strains compatible

1 'Bunching' of one strain, no clear zone between swarms

2 Pronounced 'bunching', clear zone less than $1 \mathrm{~mm}$ between swarms

3 Pronounced 'bunching', clear zone 1 to $10 \mathrm{~mm}$ wide

4 Pronounced 'bunching', clear zone more than $10 \mathrm{~mm}$ wide
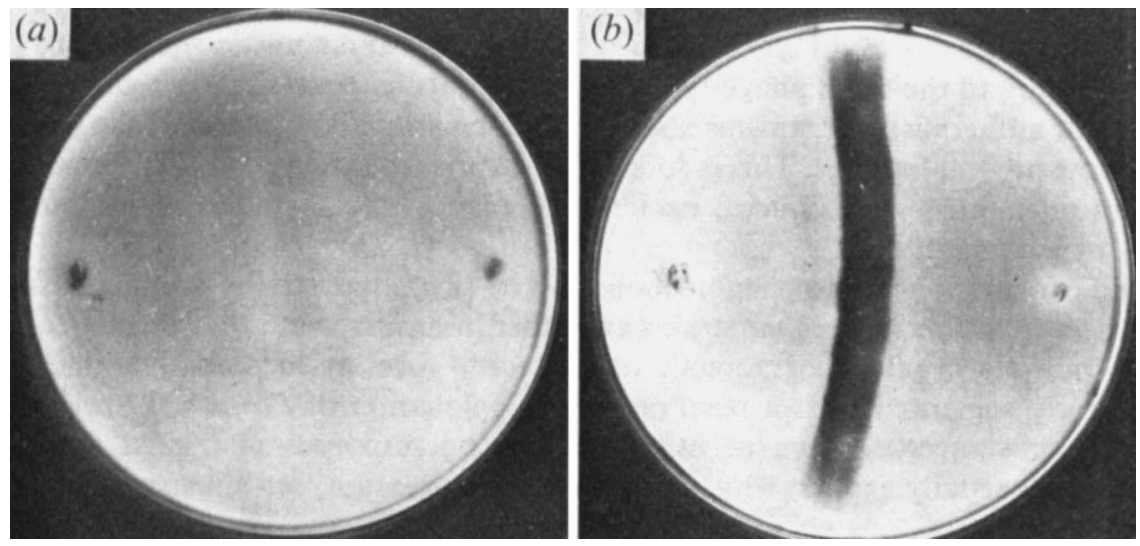

Fig. 1. (a) Complete merger of strains; score 0. (b) Pronounced incompatibility, with bunching, and a clear zone over $10 \mathrm{~mm}$ wide; score 4 .

Table 3. Incompatibility reactions between strains of Salmonella typhimurium

For details of scoring, see Table 2 and Fig. 1.

\begin{tabular}{|c|c|c|c|c|c|c|c|c|c|c|c|}
\hline \multirow{2}{*}{$\begin{array}{l}\text { Groups } \\
\text { of } \\
\text { strains }\end{array}$} & \multicolumn{11}{|c|}{ Incompatibility reaction between groups of strains } \\
\hline & I & II & III & IV & V & VI & VII & VIII & IX & $\mathrm{X}$ & XI \\
\hline I & 0 & & & & & & & & & & \\
\hline II & 0 & 0 & & & & & & & & & \\
\hline III & 0 & 0 & 0 & & & & & & & & \\
\hline IV & $0-1$ & 0 & 0 & 0 & & & & & & & \\
\hline $\mathrm{V}$ & $0-1$ & $1-2$ & $1-2$ & 1-2 & 0 & & & & & & \\
\hline VI & 2 & 2 & 2 & 2 & 2 & 0 & & & & & \\
\hline VII & 1 & 1 & 2 & 2 & $0-2$ & 2 & $\mathbf{0}$ & & & & \\
\hline VIII & 3 & 3 & 3 & 3 & 3 & $2-3$ & $2-3$ & 0 & & & \\
\hline IX & 3 & 3 & 3 & 3 & 3 & $2-3$ & 3 & 3 & 0 & & \\
\hline$X$ & 3 & $0-2$ & 4 & 4 & 4 & 3 & 4 & 4 & 4 & 0 & \\
\hline XI & 0 & 1 & 4 & 4 & 4 & 2 & 4 & 4 & 4 & 3 & 0 \\
\hline & I & II & III & IV & V & VI & VII & VIII & IX & IX & XI \\
\hline
\end{tabular}

The results of testing all strains against each other are given in Table 3. Pairs of strains, other than those giving reactions of types 3 and 4, developed their characteristic reaction within $1 \mathrm{~d}$, by which time the swarms had come close enough to give either reactions of full compatibility or incompatibility reactions of types 1 or 2 . When two strains normally giving a reaction of type 3 or 4 were inoculated, they approached each other to within $1 \mathrm{~mm}$ but did not meet. One strain then gave the impression of pushing the other one backwards; often it advanced to cover the area previously occupied by the other strain, which retreated and the density of bacteria nearest the demarcation point increased. The area between the two colonies remained clear despite being previously covered by organisms of the retreating colony. 
Strains T01, T42, T179, X63, X232, B356 and X414 were tested against each other for bacteriocin production. They all grew equally well across the line of the killed strain, showing that the incompatibility could not be explained by bacteriocin production.

\section{DISCUSSION}

The cause of the phenomenon described here is unknown. Bettelheim (1977) has shown that antigenic differences are not responsible for it. The antagonism between strains of the same species may be due to phage production by one member of the pair, but this seems unlikely as some strains of different phage-types were not antagonistic whilst some pairs of strains belonging to the same phage-type were antagonistic. Bacteriocin production by one of the pair of antagonistic organisms also seems to be an unlikely cause of the antagonism in view of the present findings. This is somewhat surprising as Senior (1977) showed that, in the Dienes phenomenon of Proteus, bacteriocins play a crucial role in many, but not all, examples of incompatibility.

A broad explanation of the phenomenon may be that some strains produce a substance or substances to which some other strains are either insensitive, and thus form a compatible pair, or produce a negative chemotactic response and form an incompatible pair. Sturdza (1977) recently suggested such a reaction as an explanation of Proteus swarming. If it is shown that substances eliciting negative chemotactic responses in related strains really exist, it would partially explain why, in an ecological situation, certain strains can displace one another.

The photography of Mr G. Bruggemans of the Clinical Photography Department of Wellington Hospital is gratefully acknowledged. I am most grateful to Miss S. M. Harding for providing strains T01, T42 and T179 as well as all the wild strains designated X, and to Miss D. M. Norris for providing the wild strains designated B. Helpful discussions with Miss S. M. Harding, Professor N. P. Markham and Dr D. R. Martin are gratefully acknowledged. Published with the authority of the Director-General of Health, Department of Health, Wellington, New Zealand.

\section{REFERENCES}

Abbott, J. D. \& Shannon, R. (1958). Method of typing Shigella sonnei using colicine production as a marker. Journal of Clinical Pathology 11, 71-77.

Bettelheim, K. A. (1977). Colony incompatibility among strains of Salmonella. Proceedings of the 1st Conference on Microbial Ecology, Dunedin (in the Press).

Bettelheim, K. A. \& Carlile, M. J. (1976). Colony incompatibility in bacteria. Nature, London 264, 757-758.

Coktzee, J. N. (1972). Genetics of the Proteus group. Annual Review of Microbiology 26, 2354.

Senior, B. W. (1977). The Dienes phenomenon: identification of the determinants of compatibility. Journal of General Microbiology 102, 235-244.

SturdzA, S. A. (1977). Expansion phenomena of Proteus cultures. II. The pushing expansion. Zentralblatt für Bakteriologie, Parasitenkunde, Infektionskrankheiten und Hygiene (Abteilung I, Originale A) 238, 444-474. 